\title{
PENGARUH KUALITAS PRODUK DAN HARGA TERHADAP KEPUTUSAN PEMBELIAN MOTOR HONDA BEAT
}

\author{
Morganda Silaban ${ }^{1)}$ \\ 1) Mahasiswa Program Studi Manajemen FE UNKRIS \\ Sunartiyo ${ }^{2)}$ \\ 2) Dosen Program Studi Manajemen FE UNKRIS \\ Alamat: Kampus UNKRIS, Jatiwaringin Jakarta Timur \\ Email: tiyosunartiyo85238@gmail.com
}

\begin{abstract}
This study aims to determine the effect of product quality and price on purchasing decisions of Honda Beat motorcycles simultaneously and partially on Honda Jatiwaringin consumers. In addition this study also aims to determine whether there are differences in consumer perceptions on the independent variable of the study when viewed from demographic factors (age, gender, income). Purposive Sampling is a sampling technique in this study. Research data were obtained by distributing research questionnaires about product quality, prices and purchasing decisions to 100 respondents. Multiple regression analysis, $F$ test, $T$ test is a data analysis technique in this study using the IBM SPSS Statistics 23 application. The results of the study show that (1) Product quality and price have a simultaneous effect on purchasing decisions, (2) Product quality and price influence partially on purchasing decisions, (3) there were no differences in consumer perceptions on each of the independent variables of the study when viewed from demographic factors.
\end{abstract}

Keywords: Product quality, price, purchase decision

\section{PENDAHULUAN}

Pada era persaingan yang begitu ketat saat ini, manusia dituntut untuk dapat menerapkan efisiensi dan efektifitas dalam semua aktivitasnya, begitu pula dalam hal mobilitas dari satu tempat ketempat lain. Hal ini tentu akan berpengaruh terhadap pemilihan alat transportasi yang akan digunakan. Dalam kondisi saat ini, dari semua alat transportasi yang ada, sepeda motor menjadi favorit masyarakat karena dianggap paling efektif dan efisien.

Pilihan masyarakat ini tentu menjadi sebuah peluang besar bagi pelaku bisnis otomotif, terutama dibidang kendaraan bermotor roda dua, untuk terus menggenjot penjualannya dengan penerapan strategi pemasaran yang tepat. Inovasi yang dapat memenuhi kebutuhan dan selera konsumen mutlak diperlukan jika pelaku bisnis tidak ingin kehilangan konsumennya serta menumbuhkan permintaan akan produknya.

Perusahaan sepeda motor saat ini mempunyai dealer motor yang menjual sepeda motor dengan macam-macam tipe. Perusahaan sepeda motor dari bermacam merk selalu melakukan inovasi terhadap produk sepeda motor yang untuk memenuhi kebutuhan konsumen. Saat ini bahkan perusahaan sepeda motor sering melakukan potongan harga terhadap penjualan, dengan cara ini banyak perusahaan sepeda motor baru melakukan nya untuk meningkatkan bisnis perusahaan.

Bagi Kotler dan Armstrong (2012), Kualitas produk ialah kinerja sesuatu produk dalam menunjukkan peranan nya, di dalam nya ada ketahanan jangka panjang, konsistensi, ketelitian, mudah untuk digunakan, serta komponen lainnya. 
Beberapa mutu produk diatas yang menjadikan konsumen yakin akan mutu produk yang dibagikan. Sepeda motor Honda tipe Beat memiliki berbagai keunggulan dan karakteristik sendiri untuk di deskripsikan terhadap beberapa dimensi produk antara lain: 1). Daya tahan (durabilitas); Honda Beat membagikan jasa garansi mesin produk tenggang lima tahun, hal ini menunjukkan sepeda motor Honda Beat mampu bertahan sampai lebih dari 5 tahun. 2). Kehandalan (reabilitas); Panjangnya mencapai $1.856 \mathrm{~mm}$, lebar $666 \mathrm{~mm}$ dan tinggi $1.068 \mathrm{~mm}$. Konfigurasi itu punya kelebihan, Beat jadi lebih mudah diajak bermanuver alias lincah. Cocok untuk penggunaan di perkotaan yang kondisi jalannya padat. 3). Kinerja; Jantung mekanis Beat eSP telah disetel Honda agar irit mengolah bahan bakar. Dengan ruang silinder berkapasitas 108,2cc berdiameter langkah 50x55,1mm, skutik andalan Honda itu mampu meraih jarak tempuh yang cukup jauh. Hal ini didasari dari pengujian yangdilakukanpabrikanberlambang sayap tunggal itu menggunakan metode ECE R40. Hasilnya, pengetesen yang memakai fitur ISS mendapatkan torehan $59 \mathrm{~km} / \mathrm{l}$ (Euro3) dan $63 \mathrm{~km} / \mathrm{l}$ (Euro2). Sementara tanpa ISS meraih $55 \mathrm{~km} / \mathrm{l}$ (Euro3) dan $57 \mathrm{~km} / \mathrm{l}$ (Euro2). (https://www.oto.com)

Tujuan yang ingin dicapai dari penelitian ini adalah intuk mengetahui pengaruh kualitas produk dan harga terhadap keputusan pembelian Honda Beat.

\section{LANDASAN TEORI}

\section{Kualitas Produk}

Kualitas produk ialah kinerja sebuah produk untuk membuktikan tugasnya (Rundh, 2005). Definisi lain yaitu kualitas produk sesuai kapasitas yang difungsikan (Albino et al., 2009). Kualitas produk menyangkut ketahanan umum suatu produk, keandalan, ketepatan, kemudahan pengoperasian, peningkatan, dan atribut berharga lainnya. Meskipun beberapa atribut dapat diukur, dari sudut pandang pemasar, kualitas produk harus diukur dengan persepsi pembeli (Deliya dan Parmar, 2012). Kualitas produk juga harus ditentukan oleh cara konsumen memandang produk. Di luar tingkat kualitas produk, kualitas tinggi juga berarti pengiriman tingkat kualitas target yang konsisten kepada konsumen. Dalam pengertian ini, kualitas produk berarti tidak ada kerusakan dan variasi. Semua perusahaan harus mengupayakan konsistensi kualitas tingkat tinggi (Rundh, 2005). 1). Ketahanan umum suatu produk. 2). Keandalan. 3). Ketepatan. 4). Kemudahan pengoperasian. 5). Peningkatan dan atribut berharga lainnya. (Deliya dan Parmar, 2012)

\section{Harga}

Menurut Kotler (2009), harga adalah jumlah uang yang ditukarkan konsumen dengan manfaat dari memiliki atau menggunakan produk dan jasa. Harga berperan sebagai penentu utama pilihan pembeli. Harga merupakan satu-satunya elemen bauran pemasaran yang menghasilkan pendapatan, elemen-elemen lain menimbulkan biaya. Berlandaskan persaingan selain berbasis pada penilaian biaya, keinginan atau keuntungan harga juga dapat ditentukan melalui basis persaingan, ialah apa yangdilakukan kompetitor. Teknik penetapan harga berlandaskan persaingan memiliki atas 4 bagian: customary pricing, above, at, or below market pricing, loss leader pricing, sealedbid pricing.

Pengukuran harga menurut Kotler dan Armstrong (2012), ada 4 indikator yang mencirikan harga yaitu: 1). Keterjangkauan harga. 2). Kesesuaian harga dengan kualitas produk. 3). Daya saing harga, dan 4). Kesesuaian harga dengan manfaat. 


\section{Keputusan Pembelian}

Menurut Schiffman dan Kanuk (2004), keputusan pembelian merupakan pertimbangan dari beberapa pilihan, yaitu konsumen dapat memutuskan, ada beberapa pilihan yang lain. Keputusan untuk membeli bisa dilakukan dari beberapa pertimbangan yang sudah ditentukan. Assauri dalam Sahetapy, (2013) mengutarakan bahwa Keputusan pembelian yaitu setiapprosespengambilan keputusan terhadap pembelian yang meliputi penentuan apa yang akan dibayar atau tidak melaksanakan pembelian\&keputusanitu dihasilkan dari kegiatankegiatan sebelumnya. Sedangkan menurut Kotler (2009) menyatakan bahwa Keputusan pembelian adalah suatu proses penyelesaian masalah yang terdiri dari menganalisa kebutuhan dan keinginan, pencarian informasi, penilaian sumbersumber seleksi terhadap alternatif pembelian, keputusan pembelian, dan perilaku setelah pembelian. Dalam mempelajari keputusan pembelian konsumen, seorang pemasar harus melihat hal-hal yang berpengaruh terhadap keputusan pembelian dan membuat suatu ketetapan konsumen membuat keputusan pembeliannya.

Indikator dari keputusan pembelian dalam Soewito (2013): 1). Kebutuhan yang dirasakan. 2). Kegiatan sebelum membeli. 3). Perilaku waktu memakai. 4). Perilaku pasca pembelian.

\section{METODE PENELITIAN}

Populasi dalam penelitian ini berjumlah 100 responden. Teknik pengambilan sampel secara sampling acak. Dikarenakan populasi di Keluarahan Jatiwaringin berjumlah 100 responden maka peneliti mengambil semua populasi untuk dijadikan sampel. (Sugiyono, 2016).

Metode pengumpulan data yang digunakan dalam penelitian ini yakni dengan data primer. Teknik analisis data yang digunakan dengan metode analisis regresi linear berganda.

\section{HASIL PENELITIAN DAN PEMBAHASAN}

\section{Hasil Penelitian}

Tabel 1. Pengaruh Kualitas Produk dan Harga Terhadap Keputusan Pembelian

\begin{tabular}{|c|c|c|c|c|}
\hline \multirow[b]{2}{*}{ Variabel } & \multicolumn{4}{|c|}{ Parameter } \\
\hline & $\mathbf{R}^{2}$ & Konstanta & $\begin{array}{c}\text { Koefisien } \\
\text { Regresi }\end{array}$ & Sig. \\
\hline $\begin{array}{l}\text { Kualitas Produk } \\
\text { Harga }\end{array}$ & 0,862 & 0,779 & $\begin{array}{l}0,353 \\
0,605\end{array}$ & $\begin{array}{l}0,000 \\
0,000\end{array}$ \\
\hline
\end{tabular}

Keterangan: Variabel Keputusan Pembelian

Sumber: data diolah 2020 
Hasil analisis pada tabel 1 , koefisien determinasi $\left(\mathrm{R}^{2}\right)$ adalah mengukur seberapa jauh kemampuan suatu model dalam menerangkan variasi variabel terikat atau Y. Besaran nilai $\mathrm{R}^{2}$ dalam penelitian ini sebesar 0.862 artinya $86,2 \%$ keputusan pembelian dapat dijelaskan oleh variabel kualitas produk dan harga, sedangkan sisanya 13,8\% dijelaskan oleh variabel lain yang tidak diteliti.

$$
\text { Persamaan Regresi } Y=0.779+0,353 \mathrm{X}_{1}+0,605 \mathrm{X}_{2}
$$

Koefisien regresi kualitas produk bertada positif jika tiap pertambahan kualitas produk, maka keputusan pembelian akan ada peningkatan perbaikan dengan asumsi harga konstan. Koefisien regresi harga bertanda postif, artinya jika ada peningkatan harga, maka ada peningkatan perbaikan keputusan pembelian dengan asumsi kualitas produk tetap.

\section{Pembahasan}

\section{Pengaruh Kualitas Produk Terhadap Keputusan Pembelian}

Berdasarkan hasil penelitian menunjukan bahwa kualitas produk dan harga berpengaruh terhadap keputusan pembelian. Hal ini dikarenakan kualitas produk Honda Beat mampu bersaing jadi menjadi market leader dalam penjualan di Indonesia. Hasil penelitian ini sejalan dengan penelitian yang dilakukan oleh Igir et al, dan Kristian \& Widayanti, 2016, yaitu menganalisis pengaruh kualitas produk dan harga terhadap keputusan pembelian.

\section{Pengaruh Kualitas Produk Terhadap Keputusan Pembelian}

Berdasarkan hasil penelitian yang telah dilakukan maka hasil tersebut menyatakan kualitas produk mempunyai dampak yang positif dan signifikan terhadap keputusan pembelian. Hal ini dapat dperhatikan dari banyaknya pengguna Motor Beat di kalangan masyarakat dan mendapat respon yang baik dalam menggunakan motor Honda Beat. Hasil penelitian ini sejalan dengan penelitian yang dilakukan oleh Habibah \& Sumiati, 2016, dan Rahayu, \& Haryanto, 2017, yaitu menganalisis pengaruh kualitas produk terhadap keputusan pembelian.

\section{Pengaruh Harga Terhadap Keputusan Pembelian}

Berdasarkan hasil penelitian yang telah dilakukan maka hasil tersebut menyatakan bahwa harga memiliki pengaruh positif dan signifikan terhadap keputusan pembelian, hal ini khususnya di PT. Daya Motor Jatiwaringin mendapat apresiasi yang tertinggi pada orientasi hasil. Hasil penelitian ini sejalan dengan penelitian yang dilakukan oleh Islami, et al, 2015, dan Muhtarom, \& Syahrizal, 2018, yaitu menganalisis pengaruh harga terhadap keputusan pembelian.

\section{KESIMPULAN DAN SARAN}

\section{Kesimpulan}

Berlandaskan uji simultan pengaruh kualitas produk dan harga secara simultan berpengaruh positip dan signfikansi karena adanya hubungan yang searah antara kualitas produk dan harga terhadap keputusan pembelian

Berdasarkan hasil uji parsial pengaruh kualitas produk terhadap keputusan pembelian secara parsial berpengaruh positif terhadap konsumen Honda Beat di Jatiwaringin sehingga bisa dibuktikan dan diterima. Berdasarkan hasil uji parsial pengaruh harga terhadap 
keputusan pembelian secara parsial berpengaruh positif dan signifikan pada konsumen Honda Beat di Jatiwaringin.

\section{Saran}

Berlandaskan penelitian ini diperoleh saran atau kritik untuk tambahan untuk penelitian tersebut dan ataupun pelengkap yang diberikan sebagai berikut: 1). PT Daya Motor Jatiwaringin harus peka terhadap pasar dan terus melakukan inovasi agar produk yang dijual terus meningkat khususnya motor Honda Beat yang penjualan nya hampir setiap tahun meningkat dan bisa melakukan persaingan terhadap perusahaan sepeda motor lain. 2). Kualitas produk dan harga merupakan komponen penting untuk melakukan penjualan sepeda motor metik Khususnya motor Honda Beat oleh karena itu PT Daya Motor Jatiwaringin harus terus konsisten dalam menentukan harga produk untuk konsumen atau bias melakukan potongan harga agar meningkatkan penjualan, sedangkan kualitas produk dari motor tersebut sudah ada spesifikasinya mungkin bisa di tambah dengan jasa garansi perawatan mesin atau oli gratis, hal ini bisa dilakukan untuk meningkatkan keputusan pembelian konsumen.

\section{DAFTAR PUSTAKA}

Habibah, Ummu dan Sumiati. 2016. Pengaruh Kualitas Produk dan Harga Terhadap Keputusan Pembelian Produk Kosmetik Wardah Di Kota Bangkalan Madura. Jurnal Ekonomi \& Bisnis, Volume 1, Nomor 1, Maret 2016, hal. 31-48.

Igir, Friani Gloria., Tampi, Jhoni R.E dan Taroreh, Henny. 2018. Pengaruh Kualitas Produk dan Harga Terhadap Keputusan Pembelian Mobil Daihatsu Grand Max Pick Up pada PT. Astra International Tbk Diahatsu Cabang Malalayang. Jurnal Administrasi Bisnis, Vol. 6 No. 2 Tahun 2018, hal: 86-96.

Islami, Shofia Amaliani., Maharani, Nina dan Oktini, Dede R. 2015. Pengaruh Harga Terhadap Keputusan Pembelian Konsumen Pada Toko Tas Henny Kota Kembang Bandung. Prosiding Manajemen, Vol. 1, No. 2 Agustus 2015.

Kotler, Philip, diterjemahkan oleh Hendra Teguh dan Ronny A. Rusli, 2009, Manajemen Pemasaran. Edisi Millenium 1. Jakarta: PT. Prenhalindo.

Kotler, Philip and Gary Armstrong, 2012. Prinsip-Prinsip Pemasaran. Edisi 13, Jilid 1, Jakarta: Erlangga.

Kristian, Denny dan Widayanti, Rita. Pengaruh Kualitas Produk dan Harga Terhadap Keputusan Pembelian Sepeda Motor Honda Pada Mahasiswa Kampuas 1 Universitas Kristen Krida Wacana. Jurnal Ilmiah Manajemen Bisnis, Vol. 16, No. 1. Januari-Juni 2016. Hal. 45-58.

Muhtarom, Abid dan Syahrizal, Muhammad Tommy. 2018. Pengaruh Kualitas Produk dan Harga TerhadapKeputusan Pembelian Rokok Surya pada Konsumen Rokok Surya di Unisla. Jurnal Penelitian Ekonomi dan Akuntansi, Volume III No. 1, Februari 2018. Hal. 615-621. ISSN: 2502-3764.

Rahayu, Suharmi dan Haryanto, Joko. 2017. Pengaruh Kualitas Produk Terhadap Keputusan Pembelian Pada PT. Majalah Media Asuransi Indonesia. Jurnal Pemasaran Kompetitif. Vol. 1, No. 1 Oktober 2017. Hal. 64-76. ISSN: 2598-0823 (cetak)

Sugiyono, 2016. Metode Penelitian Manajemen. Cetakan Ketiga. Bandung: CV Alfabeta.

Schiffman dan Kanuk. 2004. Perilaku Konsumen. Zulkifli Kasip (alih bahasa) Edisi Ketujuh. Jakarta: PT. Indexs.

Soewito, Yudhi. 2013. Kualitas Produk, Merek dan Desain Pengaruhnya Terhadap Keputusan Pembelian 
Sahetapy, Jeofer Pratama. 2013. Diferensiasi Produk, Strategi Merek, Pengaruhnya Terhadap Keputusan Pembelian Meubel UD Sinar Sakti Manado. Jurnal Manajemen. Vol.1, No.3, Hal. 411-420 